\title{
Ciberespacio, memoria y tradición Las artes de construir el tiempo en la alta modernidad
}

\author{
Cyberspace, memory and tradition
}

The arts of building time in High Modernity

L. Nicolás Guigou*

\begin{abstract}
Resumo: Pretendemos assinalar algumas das características das dimensões ciberespaciais na contemporaneidade. Estas dimensões não podem obliterar sua necessária relação com o imaginário, as memórias e as tradições que aprofundam outras temporalidades, conjugando-se com a finitude do tempo marcado pela tecnificação e virtualização do mundo.
\end{abstract}

Palavras-chave: Ciberespaço; Tradição; Memória; Tempo

Abstract: We intend to point out some of the characteristics of the cyberspace dimensions within contemporaneity. These dimensions cannot obliterate their necessary relation with the imaginary, memories and traditions that deepen other temporalities, combining themselves with the finitude of the time marked by the technification and virtualization of the world.

Key words: Cyberspace; Tradition; Memory; Time

\section{Introducción}

Desde la reflexión antropológica, resulta una suerte de desafío tratar de establecer las tramas que aúnen las dimensiones de la memoria y la tradición con un universo afincado en la pura virtualidad y el tiempo real, atributos éstos que parecen ser propios del ciberespacio. ¿No estamos acaso frente a la desrealización del mundo, del sujeto transformándose en objeto, de mundos virtuales que suelen competir con universos reales y concretos?

* L. Nicolás Guigou es doctor en Antropología Social y profesor adjunto de la Universidad de la República, Montevidéo, Uruguay. <guigoumardero@yahoo.com.br>

\begin{tabular}{|c|c|c|c|c|c|}
\hline Civitas & Porto Alegre & v. 9 & n. 2 & p. 177-184 & maio-ago. 2009 \\
\hline
\end{tabular}


Y sin embargo, nada de esto está sucediendo. En todo caso, la desrealización del mundo comenzó hace mucho tiempo atrás que la constitución del ciberespacio. Esa suerte de mundo real ha estado acosado por diferentes representaciones que lo han colocado bajo sospecha. Hemos hablado de ideología e ideologemas, de mitos y mito-praxis, de prácticas discursivas y no-discursivas. Hemos tratado de saltar del rígido habitus al saber-hacer, a los agenciamientos, a las estrategias y modalidades de resistencia. Esto, para no referirnos a la ensoñación antropológica del ser humano, curioso objeto y sujeto de saber del cual últimamente - otro espectro de la alta modernidad - hemos sugerido que lleva a cabo elecciones racionales. Por suerte el ciberespacio, los mundos virtuales (¿o la virtualización del mundo?) nos lleva a contrapelo de la hipótesis hegeliana: lo real no es racional.

Para ello, solamente deberíamos tener presente la temporalidad del siglo 20, su barbarie mecanizada, los campos de concentración, los multitudinarios holocaustos. Un siglo, que pese a adentrarnos en el siglo 21, continúa llamándonos desde sus mitemas y evocaciones varias. Entre ellas, la del ciberespacio.

\section{El ciberespacio como escena}

Pensemos brevemente en el ciberespacio en tanto conjugación de mitemas escenificados. El ciberespacio resultaría entonces la escenificación de un carisma objetual, que en un sistema de objetos, en la sociedad espectral que va desde Benjamin a Laclau, posee varios dispositivos que evitan una y otra vez la weberiana rutinización del carisma. Un carisma, que sin embargo no reposa en sujetos concretos ni instituciones, sino en el viejo hau, en el mana, en la mirada aurética de Walter Benjamin.

Dispositivos: tratándose de la escena del ciberespacio, ya no cabe la vieja alusión al deleuziano rizoma en oposición a lo arborescente. Tampoco la ya clásica "alucinación consensual" del Gibson de Neuromancer . Los dispositivos aurético y carismáticos del ciberespacio - que ya poseen su historicidad - tienen más que ver con la construcción de una mirada de tiempo completo.

Categorías clásicas como la de alienación - para presentar una relación de extrañeza entre el mundo de sujetos y objetos -, de identificación, o bien de incorporación tecno-humana, que evocarían, también otro clásico, al Cybor de Manfred Clynes (Guigou, 2006), nos reenvían a archivos sociales que posiblemente y en poco tiempo, visitaremos con la misma curiosidad 
y distancia con que las nuevas generaciones incursionaban en los restos de aquellos dilatados mapas del cuento borgiano. ${ }^{1}$

De este modo, el ciberespacio no consiste únicamente en una superficie que habilita una nueva mirada. Dado que estamos viviendo bajo la égida de la continuidad técnica, y que la dimensión ciberespacial puede transcurrir a través de diferentes soportes, las certezas están más del lado de la clonación permanente de los seres humanos, de su imagen, repetida y reiterada innumerables veces, que de la simple relación entre ordenadores y humanos con sus mediaciones y su fantasmática virtual. Al efecto de la continuidad técnica, de la mirada de tiempo completo, le continúa la clonación de tiempo completo: nunca la especie humana produjo tantas imágenes sobre sí misma. Nunca los humanos tuvimos la posibilidad de (re) producirnos imagéticamente y enviar nuestras (¿nuestras?) imágenes para todo el orbe, o para el círculo más intimista de nuestras redes sociales, también ciber/redes, mostrándonos y demostrándonos una y otra vez.

Los quince minutos de fama que, tiempo atrás, Andy Warhol anunció que todos íbamos a tener (banalización de la imagen humana, último golpe a la figura humana 'como medida de todas las cosas'), se han visto reducidos dramáticamente en el tiempo.

\section{Miradas ciberespaciales}

Sucedánea de la mirada ciberespacial inquieta, oblicua, que quiere ver lo oculto y lo ominoso sin ser visto, sucedánea, en fin, de esa cultura voyeurista, la acción performática de la exposición y sobrexposición conforman una constante en el ciberespacio. Nadie, pues, está a salvo de la mirada del Otro, y tampoco quiere estarlo. La figura del mero narcisismo se disuelve a través de la sobrexposición virtual, de los diversos ejercicios de presencia, que confían en la iteratividad de la imagen como garantía de perdurabilidad en la evanescencia ciberespacial en que la misma es viabilizada - producida y constituida -

\footnotetext{
Vale la pena, dada su brevedad, reproducir aquí el cuento de Borges llamado, no sin razón: "Del rigor en la ciencia” : “... En aquel Imperio, el Arte de la Cartografía logró tal Perfección que el Mapa de una sola Provincia ocupaba toda una Ciudad, y el Mapa del Imperio, toda una Provincia. Con el tiempo, esos Mapas Desmesurados no satisficieron y los Colegas de Cartógrafos levantaron un Mapa del Imperio, que tenía el tamaño del Imperio y coincidía puntualmente con él. Menos Adictas al Estudio de la Cartografía, las Generaciones Siguientes entendieron que ese dilatado Mapa era Inútil y no sin Impiedad lo entregaron a la Inclemencia del Sol y los Inviernos. En los Desiertos del Oeste perduran despedazadas Ruinas del Mapa, habitadas por Animales y por Mendigos; en todo el País no hay reliquia de las Disciplinas Geográficas" (Borges, 1995, p. 128).
} 
a través de las diferentes incorporaciones de la tecné. La temporalidad se puebla de iteratividad, de repeticiones que convocan una y otra vez a otras temporalidades, a otras memorias posibles y múltiples, que sin embargo no remiten a la Flash of recognition, de Taussig (Taussig, 1993), heredera de las reflexiones benjaminianas (Benjamin,1994, 2007), y sí se afinca con más seguridad en una comunicación cada vez más hiperbólica. Se nos remite así a la finitud del Intercambio Simbólico y a las configuraciones de un estilo del imaginario que habilita la remitologización del mundo.

\section{EI don en tiempos de ciberespacio: los tiempos de la remitologización del mundo}

El Ensayo sobre el don, de Marcel Mauss (Mauss, 1950), evoca una temporalidad diferida. La relación entre las múltiples temporalidades y el don, constituye por sí misma una variable fundamental del pensamiento maussiano. Abrevando en el mundo de dones y contra-dones, emerge el tiempo como un elemento fundamental para la comprensión esencial de los procesos circulares de dones contra-dones.

Derrida, en un análisis que justamente trata de la temática del tiempo y el don, ahondando necesariamente en la obra de Mauss, escribe:

... el don no es un don, no da sino en la medida en que (da) el tiempo. La diferencia entre un don y cualquier otra operación de intercambio puro y simple es que el don da (el) tiempo. Allí donde hay don, hay tiempo. Lo que ello da, el don, es el tiempo, pero ese don del tiempo es asimismo una petición de tiempo. Es preciso que la cosa no sea restituida inmediatamente ni al instante (Derrida, 1995, p. 47).

Si el don da el tiempo, en un acto de diferir el tiempo, y esta situación de restitución del don no puede ser inmediata, esta construcción de la temporalidad está basada en la imposibilidad del dar, de dar el tiempo, en términos fenoménicos: "Dado que el tiempo no pertenece a nadie, no se puede ya ni tomarlo ni darlo. El tiempo se anuncia ya como aquello que desbarata esa distinción entre tomar y dar y, por consiguiente, también entre recibir y dar..." (Derrida, 1995, p. 13).

Entonces, si el tiempo no pertenece a nadie (Derrida, 1995, p. 13) y el don no puede ser confundido con la propia dimensión fenoménica y fáctica del don, ${ }^{2}$ es porque esa temporalidad, ese dar el tiempo, está ligado a una tradición, a un estilo de dar el tiempo.

\footnotetext{
2 "El don en sí mismo - no nos atrevemos a decir el don en sí - no se confundirá nunca con la
} presencia de su fenómeno" (Derrida,1995, p.37). 
¿Cuál sería el estilo de dar el tiempo en el trayecto ciberespacial?

Baudrillard supo postular una hipótesis interesante y apocalíptica retomando las concepciones sobre el don, antropológicamente expresadas en la figura del intercambio simbólico. En la era ciberespacial, no hay posibilidad de don - por lo tanto, no hay posibilidad de intercambio simbólico, en la medida que

Existe una incompatibilidad profunda entre el tiempo real y la regla simbólica del intercambio. Lo que rige la esfera de la comunicación (interface, inmediatez, abolición del tiempo y la distancia) no tiene ningún sentido en la del intercambio, donde la regla exige que lo que se da jamás sea devuelto inmediatamente (Baudrillard, 1996, p. 49).

A las críticas expresadas desde el saber antropológico a las generalizaciones baudrillarescas - en tanto las singularidades culturales admiten temporalidades varias, tanto como múltiples maneras de intercambio - corresponde también profundizar acerca del intercambio simbólico en términos experenciales.

Si acaso la experiencia simbólica requiere de la discontinuidad de la misma - estos es, el desacoplamiento por parte de los sujetos de las exigencias sociales colonizadoras (significante dominante) - reflexión ésta que va desde las posturas marcusianas (Marcuse, 1985) hasta las expresiones más sustancialistas de Gilbert Durand (Durand, 1995) -, la contemporánea irrupción ciberespacial de tiempo continúo, impediría el arribo de lo experencial simbólico en cuestión. Dado que levistraussianamente, una sociedad nunca es totalmente simbólica, invirtiendo de este modo los términos, y llevándonos según Lévi-Strauss a considerar no el origen social de lo simbólico y sí el origen simbólico de lo social (Lévi-Strauss, 1991), las lagunas inevitables que emergerían de esta incompletud simbólica no tendrían lugar en nuestra contemporaneidad, en la medida que no se puede dar el tiempo, no se puede dar el don, ya que se habría esfumado la temporalidad necesaria propia al Intercambio simbólico. De allí la desesperación de mnemósine, la diosa de la memoria, cuya trama es el tiempo. A la fragmentación de la memoria y la disipación del tiempo, correspondería también una suerte de intercambio simbólico signado por las performances imaginarias de corte agonísticos. Desde este lugar teórico, la remitologización del mundo tendría que ver con aquella atemporalidad del bricoleur, capaz de constituir universos mitológicos con restos de discursos y acontecimientos, pero no ya bajo el ordenamiento de una matriz inconsciente, y sí por la atemporalidad de no poder dar el tiempo. En este sentido, cabe establecer dos hipótesis fuertes: la primera que a la obturación del intercambio simbólico le sigue una remitologización del mundo de corte regresivo. La 
segunda, más de cariz antropológico, tiene que ver con la remitologización del mundo, pero considerando que la temporalidad ciberespacial conforma una nueva remitologización mediante la reconstitución semántica de un universo cultural dividido, fragmentado, y de tiempo continuo. Profundicemos en estas dos posibilidades.

\section{Remitologizaciones del mundo}

¿Qué significaría una remitologización regresiva del mundo? Esta evocación resulta por demás interesante, y bien la podríamos colocar en el marco de las miradas apocalípticas tan usuales hoy en día. Si acaso estamos en una época de colonización plena del mundo de la vida, en un desfasaje entre el dar el tiempo y la falta de tiempo, en la intervención ciberespacial de los cuerpos, de la mirada, dicha desrealización del mundo impediría una experiencia simbólica auténtica (Durand, 1995), o bien nos encontraríamos bajo la gestación de una cultura tanática cuya característica estaría centrada en la desublimación represiva (Marcuse, 1985).

La regresión consistiría pues en considerar que la tecné augura una liberación de los cuerpos, de las constricciones espacio-temporales y de todas las modalidades superyoicas, habilitando de este modo remitologizaciones plenamente destructivas (y en ese sentido regresivas). De esta forma, la liberación ciberespacial, sería un anuncio más de aquella pérdida de sentido basada en la desdramatización de la destructividad, en el goce pleno del sujeto transformado en objeto, y amante pleno de sus mutilaciones y prótesis técnicas.

Si por otra parte, el tiempo no puede ser dado, o bien la simultaneidad ciberespacial que anula la temporalidad del trayecto del don impide que el intercambio simbólico se efectúe - quedando la propia regla del intercambio en entredicho, con los posibles efectos sobre las estructuras psíquicas que lo sustentan -, de allí a la desimbolización de lo social habría un paso, en la media que la dimensión comunicacional está constituida en y por el intercambio simbólico (Guigou, 2004) .

De esta forma, tampoco habría, retomando la marcusiana desublimación represiva, espacio para la experiencia simbólica, la duraniana "experiencia simbólica auténtica", habilitante de la conformación de universos simbólicos y de una dialógica imaginaria más allá de la colonización continuada hoy llevada al paroxismo por una conexión ciberespacial de tiempo continuo.

Tanto el intercambio simbólico y su finitud al paso del tiempo, así como la posibilidad de experiencias simbólicas se encontrarían obturadas por esa 
conexión permanente, por esa incorporación imperativa de la virtualización de lo social, situación que nos lleva a preguntarnos: ¿no invocaría el ciberespacio el final tan augurado de la desrealización de lo social?

¿Tal vez una vía privilegiada de la salida de lo simbólico de lo social, de la concreción de la espectralidad de lo social? Desde ese lugar, el ciberespacio asumiría así la escenificación nunca concluyente y por eso agonística de nuestra cultura.

Evidentemente, que la relevancia de los trayectos reales-virtuales, no puede confundirse únicamente con esta escenificación agonística en cuestión.

Si la inmediatez del intercambio simbólico, particularmente en la versión baudrillaresca, olvida las multiplicidades y las artes de producir el tiempo en la propia dimensión ciberespacial -, los soportes ciberespaciales, habilitan en esta alta modernidad tan líquida, que las tradiciones (siempre inventadas) puedan actualizarse, e reinventarse, para dar sentido y producir sentido desde sus eternos creadores, los sujetos. Los archivos virtuales son también archivos sociales que llaman a la propia temporalidad ciberespacial, en su vertiente histórica, y recuerdan que las temporalidades habitantes del ciberespacio son diferentes y múltiples.

Tendríamos así (y a modo de conclusión):

a) Temporalidades sociales-ciberespaciales no homogéneas que habilitan diversas memorias y condiciones de actualización de las posibilidades de las memorias mediante la conjunción de archivos sociales y virtuales.

b) Modalidades de subjetivación que tendrían que ver con el acoplamiento de tradiciones que no únicamente se actualizan en el mundo virtual, sino que también habilitan marcos de interpretación sociales-ciberespaciales. En esta dirección, deberían considerarse a las tradiciones no únicamente como productoras de sentido en su fidelidad consigo mismas, sino en tanto conjugación de diversas experiencias sociales-virtuales inventadas, fragmentadas y colocadas bajo nuevas orientaciones de sentido bajo las interpelaciones ciberespaciales.

En este sentido, y para finalizar, los nuevos diseños de la(s) memoria(s) y las tradiciones actualizadas e inventadas, daría cuenta de la ciberespacialidad en tanto locus que anuncia la definitiva disolución de la "figura del hombre", preocupación foucaultiana de hace unas décadas, y al mismo tiempo, anuncian nuevas modalidades de subjetivación, que se asientan en memorias y tradiciones ciber-sociales y que admiten que el frenesí de la alta modernidad, sin por ello anclar sus trayectos en las diatribas de la desrealización del mundo. 


\section{Referencias}

BAUDRILLARD, Jean. El crimen perfecto. Barcelona: Anagrama, 1996.

BENJAMIN, Walter. Libro de los pasajes. Madrid: Akal, 2007. . Discursos interrumpidos. Barcelona: Planeta-Agostini, 1994.

BORGES, Jorge Luis. Cuentos breves y extraordinarios. Buenos Aires: Losada, 1995.

DERRIDA, Jacques. Dar (el) tiempo: la moneda falsa. Barcelona: Paidós, 1995.

DURAND, Gilbert. A fe do sapateiro. Brasilia: Editora da UnB, 1995.

GUIGOU, L. Nicolás. Diseño de la etnografía y etnografía del diseño. Revista de Antropología Experimental, Sevilla, v. 6, 2006.

. Por una antropología de la comunicación. Montevideo: Udelar, 2004.

LÉVI-STRAUSS, Claude. Introducción a la obra de Marcel Mauss. In: MAUSS, Marcel. Sociología y antropología. Madrid: Tecnos, 1991.

MARCUSE, Herbert. El hombre unidimensional. Barcelona: Planeta-Agostini, 1985.

MAUSS, Marcel. Essai sur le don. In: MAUSS, Marcel. Sociologie et Anthropologie. Paris: P.U.F, 1950.

TAUSSIG, Michael. Mimesis and alterity: a particular history of the senses. London: Routledge, 1993. 